\title{
Sobre vitórias e esperanças
}

\author{
Harley E. A. Bicas, Cristina Muccioli, Mauro S. O. Campos, Mauro Goldchmit, \\ Samir J. Bechara, Vital P. da Costa
}

Vários acontecimentos, muito auspiciosos, têm enaltecido os Arquivos Brasileiros de Oftalmologia, ultimamente, a ponto de nos deixar orgulhosos pelo trabalho realizado e confiantes de que mais outras conquistas hão de se realizar. Entre essas condições mais recentes de maior relevo estão a da integração à SciELO (Scientific Electronic Library Online), que disponibiliza internacionalmente nossa publicação, conferindo-lhe um inequívoco aval de qualidade; a da incorporação a mais uma base de dados bibliográficos, a Periodica (Índice de Revistas Latino-americanas em Ciência) e ao diretório Latindex (Sistema Regional de Información en Línea para Revistas Científicas de América Latina, el Caribe, España y Portugal); a conclusão da recuperação da memória de todo o material dos números anteriores dos A.B.O. garantindo-se o acesso, via discos digitais, a resumos das publicações, autores e descritores de 1938 a 1985 (de 1986 até 2000 estão disponibilizados os textos completos); a feitura de cópias xerográficas "de segurança" para a coleção completa das publicações e sua doação às principais bibliotecas brasileiras, para a sua guarda e cuidados (vários dos primeiros volumes foram achados únicos ou raridades); e, do ponto de vista funcional, a superação de uma crônica condição de exigüidade de prazos entre o fechamento editorial de um número e sua distribuição. (Ao contrário, agora trabalhamos com uma folga de margem tão ampla que já começa a preocupar, exigindo novas soluções.). Tais conquistas são conseqüências de um quadro mais amplo de servidores e de uma sistemática de trabalho impulsionada por eficiência e entusiasmo crescentes. Tudo sustentado por um decidido e incondicional apoio do C.B.O. do qual, aliás, os A.B.O. se tornaram patrimônio de valor incalculável, a "pedra" de sua coroa, em celebérrima solenidade ocorrida em setembro de 2000, no Congresso de Prevenção da Cegueira e Reabilitação Visual, em Natal. Então oficializava-se "de jure" o que já era realidade "de facto", confirmando o que se anunciara em outra emocionante cerimônia (em fevereiro do mesmo ano, em São Paulo, no Simpósio Moacyr Álvaro) .

Mas de todas as glórias já vivenciadas, a da melhora de qualidade da análise editorial (da qual é fator fundamental a consciência de valor assumida por nossos conselheiros editoriais, efetivos e "ad hoc") torna-se, certamente, a mais significativa, por revelar a verdadeira fórmula de que se faz os
A.B.O.: autores mais revisores mais editoria científica, igual a qualidade substantiva ao leitor.

Um exemplo bem ilustrativo da adesão desses nossos colaboradores à causa dos A.B.O. é o que foi dado pelo comparecimento maciço deles ao curso oferecido no Congresso de Prevenção da Cegueira e Reabilitação Visual, em Pinhais (Grande Curitiba), sobre "Processos Editoriais". Tratava-se de uma peça do projeto de formação de quadros da editoração científica brasileira, mais especificamente de nossos oftalmólogos, para que cada vez mais se aperfeiçoem os processos dos A.B.O. Significativas, igualmente, foram as demonstrações de apreço ao curso dadas pelos que não puderam a ele comparecer, justificando suas ausências e as lamentando pela falta do dom da ubiqüidade (posto que deveriam atender a compromissos de exposição, em outras salas, no mesmo horário).

Credite-se boa parte desse bom sucesso ao gentil e pronto atendimento dos organizadores do Congresso a nosso pedido de mudança do horário para o qual estava preliminarmente programado o curso: tarde do último dia, em sessão cujos comparecimentos não seriam tantos, obviamente. Na verdade, o pedido foi cuidadosamente encaminhado por nossa assessoria jurídica (S. J. Bechara) mostrando, com propriedade, as razões da mudança requerida: não se repetissem as inconveniências dos horários de cursos anteriores da revista nos nossos Congressos.

Uma aposta, sim! Mas graças a todos, vitoriosa. Faltou, foi pena, tempo para debates, condição que, por certo, será corrigida no futuro. Mas, positivamente, o que prevaleceu foram comentários estimulantes, numa participação entusiasmada de interesse às exposições, que se estendeu para fora da sala, terminado o tempo. O que se viu e sentiu é que a reação dos assistentes superou a ação dos apresentadores, afrontando as leis da expectativa sobre a temática e suas possíveis motivações, mas comprovando a crença de que quando se faz por amor, recebe-se mais do que se dá.

Por isso, cabe-nos o registro de agradecimento especial a Antonio Augusto Velasco e Cruz, que substituiu um de nós (M.S.Q.C.), impossibilitado de ida ao Congresso. E, sobretudo, o de nosso muito obrigado à acalentadora manifestação de apoio a essa iniciativa dos A.B.O.: uma festa, um congraçamento de propósitos e esperanças, que só nos deve dar mais coragem para, em tal lenta mas irreversível construção, empenharmo-nos (todos) mais. 